Article

\title{
Disaster-Recovery Social Capital and Community Participation in Earthquake-Stricken Ya'an Areas
}

\author{
Zhichao $\mathrm{Li}^{1, *}$ and Xihan Tan ${ }^{2}$ \\ 1 School of Political Science and Public Administration, East China University of Political Science and Law, \\ Shanghai 201620, China \\ 2 School of Public Administration, University of Electronic Science and Technology of China, Chengdu 611731, \\ China; 2016120301016@std.uestc.edu.cn \\ * Correspondence: 2863@ecupl.edu.cn; Tel.: +86-21-5709-0125
}

Received: 18 December 2018; Accepted: 7 February 2019; Published: 15 February 2019

check for updates

\begin{abstract}
Social capital plays a significant role in post-disaster community participation and disaster recovery. This study divides social capital into three aspects: Cognition, structure, and relation, and discusses the impact of these factors on community participation in post-disaster recovery. Through data analysis, we found that a self-organized relationship villager network had a positive effect on villagers' participation in voluntary community activities after an earthquake, while the local cadre relationship network had a negative impact. However, the latter could encourage villagers to participate in disaster-recovery activities organized by the local government. These findings indicate that the mobilization mechanism for post-disaster local-government reconstruction and community self-organization are the same, both coming through the social-acquaintance network, a type of noninstitutionalized social capital. The implication of this study suggests that local government should attach much importance to the construction and integration of social networks in earthquake-stricken areas to cultivate community social capital.
\end{abstract}

Keywords: social capital; community participation; disaster recovery; local government; community self-organization

\section{Introduction}

China is among the countries that are frequently faced with disasters, and various disasters related to natural hazards that take place in China often cause severe damage. In recent years, the frequency and damage caused by disasters have gradually increased [1]. Thus, post-disaster recovery has become a tricky problem that governments and victims have to face. When natural hazards strike human society and significantly impact it, we define them as "disasters" [2]. Therefore, for disasters related to natural hazards, researchers pay more attention to the social factors involved in the hazard-preparation stage, activation stage, and recovery stage beyond the physical consequences after occurring.

On 20 August 2013, an earthquake measuring of 7.0 magnitude occurred in Ya'an, China. Lushan, Baoxing, and Tianquan counties were the hardest-hit areas in Ya'an, and are mountainous rural areas. Governments at all levels and communities played important roles in the process of post-disaster reconstruction. Among them, community participation was critical to post-disaster recovery [3,4]. Social-capital factors, such as the characteristics of interpersonal relationship networks and community reciprocity norms, also influenced community participation in post-disaster recovery [5]. Therefore, it is of vital importance to discuss the impact of formal institutions (local government) and informal institutions (social capital, relationship networks, etc.) on community participation after a disaster, both theoretically and practically. 
After the catastrophe, we launched a questionnaire survey in the earthquake-stricken area. We found that the villagers, as a mainstay of post-disaster recovery, were mobilized by different types of organizations in the process of post-disaster recovery. The survey data showed that the proportion of villagers participating in self-organized disaster-recovery activities was $37.1 \%$, and the proportion of participating in disaster-recovery activities initiated by local government was $18.5 \%$. There were very few villagers participating in both survey types: Only $2.2 \%$ of the total (The survey is outlined in more detail in Section 3).

These results may be explained as follows: After a major disaster, Chinese government at all levels usually plays a leading role in post-disaster recovery, immediately mobilizing a large amount of material and social resources for disaster-relief activities [6]. However, due to enormous destructive effects, disasters often lead to temporary failure of formal institutional system operations at disaster-stricken areas [7]. Under these circumstances, informal social capital and social-relationship networks can fill the vacuum due to the absence of formal institutions. As Soloman [5] also found in their study, villagers would turn to their relatives, neighbors, friends, and other organizations for various types of support, who performed a vital role in returning victims to their normal life.

Under specific situations, particularly in post-disaster recovery, how does an informal system (social-relationship network) mobilize social members to participate in post-disaster reconstruction activities? What are the differences between the mobilization of the community's self-organization and local government? How does the existing social capital of the community and local government influence community participation? This study answers the above questions by quantitative analysis.

This study is arranged as follows: Section 1 introduces the research questions. Section 2 is the review of post-disaster community participation from the perspective of social capital, which then proposes our research hypotheses. Section 3 is mainly about our research method and statistical models. Section 4 reveals the statistical results. Section 5 presents our conclusions and further discussions.

\section{Literature Review and Research Hypothesis}

\subsection{Community and Community Participation}

The definition of "community" is rich and diverse, without a uniform standard. German sociologist Tönnies first proposed the concept of "community". He believed that the community was a shared community with a close, friendly, and caring relationship between commune members [8]. Maclver further extended the definition. He pointed out that "any local village, county, city, or country where people live together can be called a community [9]". Later, some scholars also defined community differently, but there was a consensus regarding regionality [10,11]. When incorporating the concept "community" into rural China, regionality is concretized. Community is the area under the jurisdiction of the village committee, which generally refers to the village-committee area that has made scale adjustment after reform of the rural-community system [12]. Putnam, in his classical community research, investigated the changes in social capital in American communities through trust, social networks, and community norms. Therefore, this study regards social networks as an indispensable element of the concept of "community" [13].

As the bottom unit of society, community has a natural connection with disasters. It is not only the subject of disasters, but also the main body of action for disaster recovery [14]. Disaster-emergency management can be divided into four phases: Preparedness, response, mitigation, and recovery [15]. In China, due to the top-down governance model [16], the government usually plays more roles during the first two phases [6], while communities, as informal institutions, are more likely to have positive effects in the last two phases [17].

Therefore, combined with the reality of earthquake-stricken areas in Ya'an, this study defined the community as follows. Based on a blood relationship, a community is an important noninstitutional force in post-disaster recovery, with the characteristics of reciprocity, trust, and social networks in the jurisdiction of a village committee. 
Community participation has different meanings in different situations. In a disaster situation, Maskrey found that [18] "people were able, through community-based organizations (CBOs), to articulate strategies for recovery and reconstruction that responded to their real needs". Through our investigation we found that after the earthquake, villagers were mobilized by formal or informal institutions to participate in the community, such as in neighborhood mutual assistance, district patrols, and public-facility construction, mainly aiming to promote rapid community recovery and sustainable development.

\subsection{Community Participation in Post-Disaster Recovery Activities from the Perspective of Social Capital}

Since the French sociologist Bourdieu first introduced the concept of "social capital" into sociological research, it has become a popular concept in social science [4,19]. Bourdieu [20] regarded social capital as an aggregation of actual or potential resources that were more or less associated with institutionalized networks of mutual understanding and cognition. Later, Boudieu's social capital, including various social resources, such as networks, social claims, social relations, affiliations, and associations [21], as one of several assets (physical capital, natural capital, economic or financial capital, human capital and social capital) [22], also formed an essential part of the "sustainable-livelihoods approach".

Classical disaster sociology analyzed disaster consequences and post-disaster reconstruction from the perspective of social capital [23]. Social capital can be divided into micro and macro. Micro-social capital refers to the interpersonal-relationship network and its social resources that can bring benefits to individuals through social interaction. Hurlbert [24] discussed the relationship between the micro-social capital of victims and post-disaster reconstruction, finding that victims' mobilization of social resources in a social network after a disaster directly affected the recovery effect. Macro-social capital refers to the social network and its reciprocities that can promote the generation of collective actions and the achievement of common goals [25]. Sung [26] found that macro-social capital such as community trust and reciprocity norms had a significant positive impact on community participation in post-disaster recovery. Furthermore, Nahapiet and Ghoshal [27] divided social capital into three forms: Relational social capital, established by the long-term interaction of social members through social networks; network configuration of the structural social capital accumulated by social ties; and cognitional social capital, set up by social members based on common rules, language, and experience.

Although the above studies provide a basic perspective for discussing community participation in post-disaster recovery, they are all based on the Western social background. China, on the other hand, has a cultural tradition emphasizing interpersonal ethic relationships. In the context of local society, social capital is usually represented as an operation of acquaintance ties (favor exchange). In other words, in the interpersonal-relationship network of differential modes of association (chaxu geju), instrumental behavior and emotional behavior are constantly dynamically balanced [28,29]. In addition, political power deepens in the countryside and creates an overlap between vertical authority and social-relation logic [30]. Therefore, the function of localized social capital undoubtedly plays an essential role for community participation in post-disaster reconstruction. This study attempted to combine the rural social situation with social-capital theory to explore what the mechanism was through which social capital influenced community participation in post-disaster reconstruction activities [29]. 
2.2.1. Cognitional Social Capital: Role of Community Identity in Post-Disaster Reconstruction and Mobilization

According to Chinese reality and resource mobilization, the formal system, represented by government at all levels in China, is essential and irreplaceable for post-disaster recovery. This makes researchers pay more attention to the role of formal institutions in the post-disaster recovery process. For instance, how does government mobilize resources, how does its administrative system govern disasters [31], and what is the model of national counterpart aid [32]? These are state-centered disaster studies.

However, apart from the formal character of the government's disaster-relief activities, social operations after a disaster also contribute much to disaster recovery, including nongovernmental organizations, community self-organization, and social autonomy, which emerges from the disaster [33]. When a disaster strikes, a variety of spontaneous organizations, rather than the national machine, immediately mobilize villagers. Rolf [34] assumed that the capacity of a community to handle extreme events would be enhanced if community members had a strong sense of community identity and a high cohesiveness level.

Communities with high cohesion and a good sense of identity can spontaneously organize in the absence of governmental resources and support. They can rely on community self-organization to carry out post-disaster reconstruction through collective action. This kind of post-disaster reconstruction activity, based on the community identity of its members, can be regarded as a kind of "volunteer community activity". Nahapiet [27] also pointed out that community members' sense of identity and belonging to their communities were a kind of cognitional social capital that encouraged villagers to move toward collective-benefit actions. According to theoretical analysis and field observations, this study gave the following hypothesis:

Hypothesis 1. The higher the recognition for the village that villagers have, the greater the likelihood of participating in self-organized post-disaster reconstruction activities.

\subsubsection{Structural Social Capital and Community Participation in Post-Disaster Recovery}

The concept of social capital is applied in the category of community based on existing social networks, emphasizing the shared mobility of the community [35]. Putnam [36] believed that social capital was a feature of social life, and that networks could encourage participants to pursue common goals and co-operate more effectively. Therefore, synergy and trust between mutually beneficial social networks and community members are critical to community participation in disaster recovery. Some studies indicated that after disasters, social networks (relative networks, neighborhood networks) played an irreplaceable role in emergency response and social support [37,38].

Social ties can be divided into expressive ties and instrumental ties. Expressive ties are influence [39]. A person with more expressive ties in the community has greater influence on mobilizing villagers to participate in post-disaster reconstruction activities. Similarly, close relationships also mean limitations [40]. This study selected relatives and friends as acquaintance relationships. If the proportion of acquaintances in the social network is high, it indicates that villagers live in a relatively closed acquaintance network. This kind of dense and restrictive network easily mobilizes villagers to participate in post-disaster reconstruction activities. Based on the above, this study proposes the following hypothesis: 
Hypothesis 2a. Villagers' emotional-relationship network (scale and acquaintance ratio of the network) has a positive effect on villagers participating in self-organized community post-disaster reconstruction activities.

Villagers with many instrumental ties usually ask others for help. Behind the rules of Renqing (favor exchange) in China, this kind of relationship makes villagers have more favor-exchange accounts, through which it is easier to mobilize villagers to participate in post-disaster reconstruction activities [29]. Therefore, we propose the following hypothesis:

Hypothesis 2b. Villagers' instrumental-relationship network (scale and acquaintance ratio of the network) has a positive effect on them participating in self-organized community post-disaster reconstruction activities.

Western academia has mainly focused on the following topics in community participation: Which is the trust structure of community members, strong or weak trust? What is the form of social capital, bonding or bridging [41,42]? In rural communities in contemporary China, local government is an important force affecting the community. Local government in China includes three levels: Provinces (autonomous regions, municipalities), counties (autonomous counties, cities), and townships (national townships, towns) [43]. At present, there are few empirical studies on how local government influences community participation and self-organization. This study considers local government in its community-mobilization and -participation analysis. The cadre-relationship network is quite unique in Chinese social ties, significantly affecting villagers' daily lives and social attitudes [44]. Based on field research on a community's reconstruction after a 5.12 magnitude earthquake that occurred in Wenchuan, Li 38 assumed that local-government support for post-disaster community reconstruction and development might have "accidental consequences". The network established by government cadres may have an inhibitory effect on community self-organization, which is not conducive to community members' participation in spontaneous and voluntary reconstruction activities. In the field observation of the village-reconstruction process after the earthquake in Ya'an, we also found that villagers who were familiar with township cadres or on a senior level were less involved in self-organized community disaster-recovery activities, while they were more willing to participate in local-government organizations. Therefore, we hypothesized the following:

Hypothesis 3a. Villagers' cadre-relationship network (scale and acquaintance ratio of the network) has a negative effect on villagers participating in the self-organized community post-disaster reconstruction activities.

Relationship strength determines the ability to mobilize, and strong ties often have a high sense of trust [45]. Therefore, an individual's social capital is determined by private resources in the network. The stronger the relationship is, the larger the likelihood that mobilization can be put into public action [46]. Similarly, if they have many strong ties with local cadres, they are more likely to be mobilized when these cadres launch government-organized disaster relief and collective reconstruction actions. Therefore, we made the following hypothesis:

Hypothesis $3 \mathbf{b}$. Villagers' cadre-relationship network (scale and acquaintance ratio of the network) has a positive effect on the villagers participating in the self-organized community post-disaster reconstruction activities.

\subsubsection{Relational Social Capital and Community Participation in Post-Disaster Recovery}

Trust is a mediation variable between social ties to economic action [47], so "trust" is a factor that must be paid attention to in relational social capital. Trust is usually regarded as macro-social capital. Putnam [48] treated trust as an indispensable foundation for community participation. He divided trust into strong (particularistic or thick trust) and weak trust (general or thin trust). The former refers to the trust of individuals who interact with intimate networks, while the latter refers to the trust of people and institutions outside the community. According to Putnam, Chinese rural society usually 
lacks community organizations and civic-participation activities. The "publicity" of the community was weak [49], villagers' social interactions were limited to small circles, and their trust was difficult to extend to outside. Based on the above, we propose the following hypothesis:

Hypothesis 4a. Villagers' particularistic trust has a negative effect on their participation in disaster-recovery activities organized by local government.

Individuals who launch self-organized collective actions also mobilize villagers to participate in collective action through acquaintances. Therefore, if villagers have higher trust in these people, they believe that these actions were for public welfare that can benefit them. Thus, when these individuals initiate reconstruction activities, villagers are more likely to be motivated. Therefore, we also proposed the following hypothesis:

Hypothesis $\mathbf{4 b}$. Villagers' particularistic trust has a positive effect on their participation in disaster-recovery activities organized by local government.

\section{Research Method and Statistical Model}

\subsection{Data and Samples}

The data used in this study were from a questionnaire survey conducted in the earthquake-stricken Ya'an area in August 2013. The investigation was conducted by teachers and students from Sichuan University and the University of Electronic Science and Technology of China. Due to the limitation of objective conditions after the earthquake, our survey did not use random-sampling methods. Considering the scale of villages, the severity of the earthquake, dissimilarities, and other factors, we selected 20 villages from the Lushan, Baoxing, and Tianquan counties by using the judging-sampling method. Forty households were randomly selected in each location. We used Kish (a questionnaire designed by L. Kish for door-to-door sampling) [50] to extract one adult for the questionnaire in each household. In total, 687 valid questionnaires were returned, and the effective response rate was $85.9 \%$. The questionnaire not only collected villagers' basic information, but also data about their social capital and networks.

\subsection{Research Variables}

\subsubsection{Dependent Variable}

The focus of this study was to explore the influencing factors of villagers' participation in post-disaster reconstruction activities, and especially what the roles of the existing social networks in communities and local government were. We defined "post-disaster recovery activities" as activities that were public and coadjutant, like community environmental cleanup, community patrols, carrying goods and materials, and caring for the elderly and children in villages after the earthquake. The dependent variable of this study was "the condition of villagers' participation in post-disaster recovery activities". The variable assignment values were: $0=$ did not participate, $1=$ participating in reconstruction activities organized by community self-organization, and $2=$ participating in reconstruction activities organized by local government. It should be noted that there were 15 samples in reconstruction activities launched by both community self-organization and local government, accounting for $2.2 \%$ of the total number of samples. Considering the simplicity of our statistical models, we did not add this type of sample. 


\subsubsection{Independent Variable}

The key independent variable of this study was the social capital of the villagers. For cognitional social capital, we designed a set of Likert scales (adding all scores) to measure villagers' sense of identity about their villages, and summed the scores of the respondents on each topic to obtain the "community identity index" variable (more details can be found in the Appendix A).

Structural social capital was mainly embodied in the instrumental-relationship and emotional-relationship networks. The cadre-relationship network was added especially according to China's social situation. The questionnaire therefore designed three social networks of the villagers: The instrumental network (villagers who provided daily help, such as borrowing money or goods, farming, and building houses after the earthquake), the emotional network (villagers who could share their private affairs, such as marriage, pension, disease treatment, and childbirth after the earthquake), and the cadre-relationship network (local cadres that were conversant or helpful with villagers after the earthquake). Based on this, we calculated the scale of three networks separately, including the number of people in the networks and the proportion of a strong network relationship (the proportion of relatives and friends' strong relationships in the networks). It should be noted that the role of village cadres in mobilizing villagers to participate in post-disaster recovery activities was quite complicated, with both positive and negative effects [38]. Thus, we did not add "village cadres" (village secretaries/village director/village "two-committee" cadres) into the cadre-relationship network, while we placed "township cadres or senior level" in it. The measurement of the cadre-relationship network was mainly asking villagers whether they were friendly with township cadres or someone at the senior level, or whether local cadres had helped them.

"Social trust" is a key element of relational social capital, which is an important factor affecting villagers' participation in post-disaster recovery activities. In our study, some subjects were required to evaluate to which degree villagers were trusted. We used principal component analysis and, after excluding the missing values and objects with a weaker factor load, two common factors were extracted. The common factors (Table 1), the "particularistic trust" factor and the "general trust" factor, had a cumulative explanatory contribution rate of $64.59 \%$. In order to be intuitive and understandable, we numerically transformed all factor scores to a percentile variable, with a lowest score of 1 and a maximum score of 100 .

Table 1. Factor analysis of "social trust".

\begin{tabular}{ccc}
\hline Question Item & Particularistic Trust Factor & General Trust Factor \\
\hline Your family members & $0.834^{*}$ & -0.091 \\
Your best friends & $0.812^{*}$ & 0.172 \\
Neighborhoods & $0.719^{*}$ & 0.213 \\
Many villagers in the village & $0.696^{*}$ & 0.255 \\
Businessmen in the market/trading people & 0.221 & $0.812^{*}$ \\
Strangers & 0.209 & $0.801^{*}$ \\
Municipal government (or country government) & 0.148 & $0.786^{*}$ \\
Township government (or town government) & 0.121 & $0.715^{*}$ \\
Lawyers & 0.091 & $0.691^{*}$ \\
Doctors & -0.081 & $0.631^{*}$ \\
Eigenvalue & 2.387 & 1.629 \\
Cumulative variance & $27.319 \%$ & $37.271 \%$ \\
Cumulative interpretation of variation & $27.319 \%$ & $64.590 \%$ \\
\hline
\end{tabular}

$*$ indicates factor load $>0.5$.

\subsubsection{Control Variable}

In order to clarify the influence of social-capital factors on villagers' participation in post-disaster recovery activities, we introduced some control variables. These were mainly the individual characteristic variables of villagers: Gender, age, whether they were members of the Communist Party of China, years of education, and marital status. More details can be seen in Table 2: 
Table 2. Variable description.

\begin{tabular}{|c|c|c|c|}
\hline Variable Name & $\begin{array}{l}\text { Mean Value or } \\
\text { Percentage }\end{array}$ & $\begin{array}{l}\text { Standard } \\
\text { Deviation }\end{array}$ & Variable Description \\
\hline \multicolumn{4}{|l|}{ Dependent variable } \\
\hline $\begin{array}{l}\text { The condition of villagers' } \\
\text { participation in post-disaster } \\
\text { recovery activities. }\end{array}$ & $\begin{array}{l}\text { “0": } 44.4 \% \\
\text { "1": } 37.1 \% \\
\text { "2": } 18.5 \%\end{array}$ & - & $\begin{array}{c}\text { Class variable, } \\
0=\text { not participating, } 1=\text { participating in } \\
\text { pre-disaster recovery organized by community } \\
\text { self-organization, } 2=\text { participating in pre-disaster } \\
\text { recovery organized by local government. }\end{array}$ \\
\hline \multicolumn{4}{|l|}{ Cognitional social capital } \\
\hline Community identity index & 2.812 & $(0.382)$ & $\begin{array}{c}\text { Interval variable, } \\
\text { degree of recognition of villages }\end{array}$ \\
\hline \multicolumn{4}{|l|}{ Structural social capital } \\
\hline $\begin{array}{l}\text { Scale of instrumental } \\
\text { network }\end{array}$ & 4.180 & (5.265) & $\begin{array}{c}\text { Interval variable, } \\
\text { number of network memberships } \\
\text { Interval variable, }\end{array}$ \\
\hline $\begin{array}{l}\text { Ratio of strong ties of } \\
\text { instrumental network }\end{array}$ & 0.637 & $(0.377)$ & $\begin{array}{l}\text { proportion of "relative acquaintances" in the } \\
\text { network; } 0-1 \text {, "1" indicating that all the members } \\
\text { are relatives and friends. }\end{array}$ \\
\hline Scale of emotional network & 2.277 & $(1.287)$ & $\begin{array}{c}\text { Interval variable, } \\
\text { the number of network memberships. } \\
\text { Interval variable, }\end{array}$ \\
\hline $\begin{array}{l}\text { Ratio of strong ties of } \\
\text { emotional network }\end{array}$ & 0.750 & $(0.337)$ & $\begin{array}{l}\text { proportion of "relative acquaintances" in the } \\
\text { network; } 0-1 \text {, "1" indicates that all members are } \\
\text { relatives and friends. }\end{array}$ \\
\hline $\begin{array}{l}\text { Scale of township cadres or } \\
\text { senior level network }\end{array}$ & 0.685 & $(1.043)$ & $\begin{array}{l}\text { Interval variable, } \\
\text { number of network memberships. }\end{array}$ \\
\hline $\begin{array}{l}\text { Ratio of strong ties of } \\
\text { township cadres or } \\
\text { senior-level networks }\end{array}$ & 0.214 & $(0.348)$ & $\begin{array}{l}\text { Proportion of "relative acquaintances" in the } \\
\text { network; } 0-1 \text {, "1" indicates that all the members } \\
\text { are relatives and friends }\end{array}$ \\
\hline \multicolumn{4}{|l|}{ Relational social capital } \\
\hline General trust & 29.325 & $(11.187)$ & $\begin{array}{l}\text { Interval variable, } \\
\text { degree of general trust, } 1-100 ; “ 100 \text { ” indicates } \\
\text { highest degree of trust }\end{array}$ \\
\hline Particularistic trust & 38.215 & $(13.675)$ & $\begin{array}{l}\text { Interval variable, } \\
\text { degree of general trust, } 1-100 ; \text {; } 100 \text { " indicates } \\
\text { highest degree of trust }\end{array}$ \\
\hline \multicolumn{4}{|l|}{ Control variable } \\
\hline Gender & 0.404 & $(0.492)$ & $\begin{array}{l}\text { Dichotomous variable, } \\
0=\text { male }, 1=\text { female }\end{array}$ \\
\hline Age & 50.096 & $(13.648)$ & $\begin{array}{l}\text { Interval variable, } \\
\text { age grouping in the model }\end{array}$ \\
\hline $\begin{array}{c}\text { Whether they are members } \\
\text { of Communist Party of } \\
\text { China }\end{array}$ & 0.045 & $(0.208)$ & $\begin{array}{l}\text { Dichotomous variable, } \\
\quad 0=\text { no, } 1=\text { yes }\end{array}$ \\
\hline Years of education & 6.219 & (3.328) & Interval variable \\
\hline Marital status & 0.961 & $(0.195)$ & $\begin{array}{l}\text { Dichotomous variable, } \\
0=\text { unmarried, } 1=\text { married, divorced, or widowed }\end{array}$ \\
\hline
\end{tabular}

\subsection{Statistical Model}

A multivariate logistic regression model [51] was established in this study because the dependent variable (the condition of villagers' participation in post-disaster recovery activities) was a class variable, rather than an interval variable, which is unsuitable for ordinary linear regression models. We first converted the dependent variable into the probability ratio of occurrence/nonoccurrence of an event, and then examined the effect of the independent variable on the occurrence ratio. 


\section{Results}

\subsection{Significant Difference between Villagers Who Are Mobilized by Local Government or Community Self-Organization}

Foreign studies [52] on community participation pointed out that years of education were positively related to the degree of community participation. That is, the more years of education a villager had, the wider the social networks and the richer the social capital they had, making it easier for the villager to integrate into the surrounding living environment. Thus, the villager would participate in community activities more. However, our quantitative research revealed different social facts. "Years of education" was positively related with "participating in reconstruction activities organized by community self-organizations". The regression coefficient was 1.643 , and statistically significant. The influence of villagers' "years of education" on "participating in reconstruction activities organized by the local government" was not significant, which indicated that villagers with a higher socioeconomic status would be more likely to participate in post-disaster recovery activities organized by local government. Villagers might be involved in government-organized activities as a channel and an opportunity to acquire more social resources. In addition, according to social-network indicators, in the process of post-disaster recovery, the mobilization effect of local government and community self-organization on villagers was quite different. Local government often mobilized villagers who had wider connections with cadres and more years of education.

We also found that villagers who had a high sense of identity with their village were more likely to participate in self-organized post-disaster reconstruction activities, as shown in Table 3. The regression coefficient of the "community identity index" was 0.813 , which was statistically significant; hence, Hypothesis 1 was proven. However, the "community identity index" was not significant for "reconstruction activities organized by the local government" (regression coefficient was only 0.151), which was in stark contrast with "reconstruction activities organized by self-organization". Local government played a crucial part in major public community affairs of disaster-recovery activities. Community members mobilized by local government or by community self-organization had many differences in social characteristics. Studies [53,54] discuss the relationship between the social characteristics of community members and community participation generally, and do not consider the mobilization factors of local government.

\subsection{Mobilization Mechanism of Local Government and Community Self-Organization in Post-Disaster Reconstruction Activities—Both Mobilized through Acquaintance Networks}

For "self-organized post-disaster recovery activities", namely, community volunteer activities, regression coefficients of the model in "ratio of strong ties of instrumental network", and "ratio of strong ties of emotional network" were positive values (1.863 and 1.873, respectively, statistically significant). This showed that community self-organization is mainly through acquaintance networks that mix instrumental and emotional relationships. These acquaintance networks have a strong ability to mobilize members in networks [29]. The social foundation of rural-community participation (or co-operation) lies in the social form of acquaintances [55]. The key to villager participation in spontaneous post-disaster recovery activities and formation of collective action in voluntary communities was whether the community had a social network that could make villagers frequently interact with each other. Apart from that, we found that the above two variables also had a positive effect on "reconstruction activities organized by the local government" (regression coefficients were 2.439 and 1.623 , respectively, statistically significant), which meant the mobilization mechanisms for post-disaster recovery activities were similar both in local government and community self-organization, all through the acquaintance network. 
Table 3. Multivariate logistic regression model of social-capital actors affecting "villagers' participation in disaster recovery activities".

\begin{tabular}{|c|c|c|c|c|}
\hline & \multicolumn{2}{|c|}{ Community Self-Organization } & \multicolumn{2}{|c|}{ Local Government } \\
\hline & $\begin{array}{l}\text { Regression } \\
\text { Coefficients }\end{array}$ & $\begin{array}{l}\text { Standard } \\
\text { Error }\end{array}$ & $\begin{array}{l}\text { Regression } \\
\text { Coefficients }\end{array}$ & $\begin{array}{c}\text { Standard } \\
\text { Error }\end{array}$ \\
\hline $\begin{array}{l}\text { Cognitional social capital } \\
\text { Community identity index } \\
\text { Structural social capital }\end{array}$ & $0.813 *$ & $(0.125)$ & 0.151 & $(0.358)$ \\
\hline Scale of instrumental network & -0.032 & $(0.089)$ & -0.081 & $(0.085)$ \\
\hline The ratio of strong ties of instrumental network & $1.863^{* *}$ & $(0.512)$ & $2.439 *$ & (1.141) \\
\hline Scale of emotional network & -0.045 & $(0.214)$ & 0.028 & $(0.117)$ \\
\hline Ratio of strong ties of emotional network & $1.873^{*}$ & $(0.762)$ & $1.623 *$ & $(1.061)$ \\
\hline Scale of township cadres or senior level network & $-1.243 *$ & $(0.472)$ & $1.782 * *$ & $(0.602)$ \\
\hline $\begin{array}{l}\text { Ratio of strong ties of township cadres or } \\
\text { senior-level networks }\end{array}$ & $-2.398^{*}$ & $(1.076)$ & $2.578 *$ & $(1.102)$ \\
\hline \multicolumn{5}{|l|}{ Relational social capital } \\
\hline General trust & 0.143 & $(0.209)$ & $0.612 *$ & $(0.201)$ \\
\hline Particularistic trust & $0.913 *$ & $(0.414)$ & $-1.014^{*}$ & $(0.326)$ \\
\hline \multicolumn{5}{|l|}{ Control variable } \\
\hline Female & 0.082 & $(0.521)$ & 0.873 & $(1.721)$ \\
\hline Age & -0.072 & $(0.391)$ & -0.043 & $(0.185)$ \\
\hline \multicolumn{5}{|l|}{$\begin{array}{l}\text { Whether members of Communist Party of China } \\
\text { (no) }\end{array}$} \\
\hline Yes & -1.821 & $(1.312)$ & 1.432 & $(3.564)$ \\
\hline Years of education & 0.231 & $(0.277)$ & $1.643^{*}$ & $(0.286)$ \\
\hline Marital status (unmarried) & & & & \\
\hline Married, divorced, or widowed & 1.835 & $(2.243)$ & 1.239 & $(1.571)$ \\
\hline Intercept & -2.215 & (1.949) & -3.682 & (2.492) \\
\hline Chi-square & \multirow{3}{*}{\multicolumn{4}{|c|}{$\begin{array}{c}152.743 * * \\
231.674 \\
687\end{array}$}} \\
\hline - 2 Log likelihood & & & & \\
\hline $\mathrm{N}$ & & & & \\
\hline
\end{tabular}

Note: 1 . One-tailed check, ${ }^{*}: p<0.10 ;{ }^{* *}: p<0.05$. 2. Influence of social-capital factors on the participation of villagers in post-disaster recovery activities with reference to "not participating".

"The scale of the instrumental network" and "the scale of the emotional network" had no significant impact on "reconstruction activities organized by local government" or "reconstruction activities organized by community self-organization". This meant that the expansion of the network scale might lead to the attenuation of mobilization and influence. This was still a "dense network" [56] that had strong mobilization ability. In general, Hypotheses $2 \mathrm{a}$ and $2 \mathrm{~b}$ were partially proved.

\subsection{Cadre-Relationship Network Has a Negative Impact on a Community's Self-Organized Disaster Recovery Activities}

For "self-organized post-disaster recovery activities", the regression coefficient of the model on "the scale of township cadres or senior level network" was -1.243 and statistically significant. That is to say, if there were more township cadres or senior levels in the villagers' social network, the likelihood of participating in self-organized disaster-recovery activities would be greatly reduced. In sharp contrast, "the scale of township cadres or senior-level network" had a positive effect on the participation of villagers in disaster-recovery activities organized by local government. The regression coefficient was 1.782 and statistically significant. It could be seen that "the scale of township cadres or senior-level network" played a very different role in villagers' participation in voluntary community-reconstruction activities organized by local government or community self-organization.

In addition, "the ratio of strong ties of township cadres or senior-level network" had a positive effect on the participation of villagers in disaster-recovery activities organized by local government. The regression coefficient was 2.558 and statistically significant. This showed that local government's mobilization was mainly carried out through the interpersonal network of cadres. The stronger the relationship was, the greater the mobilization could be. On the contrary, this variable had a negative 
impact on villagers' participation in voluntary community-reconstruction activities. The regression coefficient was -2.398 and statistically significant. In summary, the cadre-relationship network (the size of the network and the proportion of acquaintances in the network) had a positive effect on villagers' participation in post-disaster reconstruction activities organized by local government, while it had a negative effect on community self-organization. Therefore, Hypotheses $3 \mathrm{a}$ and $3 \mathrm{~b}$ were validated by data.

\subsection{Different Trust Structures had Different Effects on Types of Villagers' Participation in Post-Disaster Reconstruction Activities}

Judging from the indicators of relational social capital, "general trust" had a positive effect on the participation of villagers in activities organized by the government (regression coefficient was 0.612 , statistically significant). In other words, villagers with higher "general trust" were more likely to be involved in local government-lead post-disaster reconstruction activities. However, the likelihood of villagers with higher "particularistic trust" who participated in reconstruction activities organized by the local government was greatly declined (regression coefficient was -1.014 , statistically significant). Thus, Hypothesis 4a was proved. In stark contrast, "particularistic trust" had a positive effect on self-organized post-disaster reconstruction activities (regression coefficient was 0.913, statistically significant); thus, Hypothesis 4b. was also supported by data. Ikenberry and Fukuyama [57] pointed out that "social trust" was an indicator reflecting the overall condition of social capital. This study divided "social trust" into "general trust" and "particularistic trust". We found that diverse trust structures generated different types of villager participation in post-disaster reconstruction activities.

Due to the "relationship-based" peculiarity of Chinese society, Chinese people's trust structure focuses more on kinship and specialism [58]. Differing from the "social trust" of Western countries, which is based on laws and formal contracts, Chinese trust is often expressed as a kind of "private trust". Private trust is based on an exchange of benefits and interests between individuals, and between individuals and organizations [59]. Particularistic trust has a diametrically opposite effect on post-disaster recovery activities organized by local government and community self-organization, which is a reflection of this kind of trust logic.

\section{Discussion and Conclusions}

Post-disaster reconstruction requires not only policy and material support at the national level, but also social capital. Therefore, cultivating social capital and enhancing community participation in the process of reconstruction are important aspects of nonstructural disaster reduction. Putnam 36 pointed out that both internal and external organization situations and social capital were the two most important factors influencing community participation. Through statistical analysis, this study found the subjects, including community self-organization and local government, who respond to the disaster, and their social capital, differently influencing community participation. Traditionally, scholars $[34,60]$ often regarded social capital as a crucial element of post-disaster recovery: Villagers who are embedded in large-scale, tightly-connected, and heterogeneous social networks in disaster-stricken areas form a therapeutic community that greatly facilitates the recovery process. However, they ignored the internal diversity within social capital and did not place them in different situations. 
This study introduced the cadre-relationship network, which is significant in China's social context. Statistical analysis showed that there was clear separation between villagers mobilized by government and those mobilized by community self-organization. This separation indicated the multiple features of the villagers' own social networks. It also showed that the heterogeneity of social capital did not necessarily contribute to higher community participation. Therefore, it is indispensable to classify social capital into different types according to specific social situations. Moreover, through analysis of the statistical results, we found that local government generally mobilized villagers through the cadre-relationship networks, rather than by using bureaucratic or administrative orders. The mechanism is similar to community self-organization mobilization through the acquaintance network. However, there is a conspicuous separation between the mobilization networks of those two patterns, and they are mutually exclusive on post-disaster recovery activities. Although local government played an extremely important role in post-disaster recovery, it also negatively influenced community self-organization. Zhao 4 argued that, if the community solely had a high level of particularistic trust, we should not be too optimistic about post-disaster recovery. Only when the trust scale breaks through acquaintance networks and extends to strangers and institutions can disaster-recovery activities be effective. If local government overlooks communication and interactions with villagers, and neglects existing villages' social networks during the post-disaster reconstruction process, it will come across various difficulties, such as antagonism between cadres and villagers, or tension in community relationships, even though physical reconstruction projects could go smoothly. As a consequence, efforts on policies and actions the governments have made would be less effective than expected [61].

Post-disaster recovery first involves the repair and reconstruction of hardware facilities, but the reconstruction and integration of social order and social networks are more important. Analysis in this study revealed that villagers' pre-disaster social networks had a significant impact on the community participation after the earthquake, reflecting the "continuity principle" in the post-disaster recovery process, namely, villagers' behavior patterns are constant [2]. Villagers' original socioeconomic statuses and relationship networks continue affecting the post-disaster recovery process. These results remind us that we should attach importance to victims' social relations and the structure of their relationship networks. In reality, local government should see post-disaster recovery as an opportunity for facilitating the formation and accumulation of community social capital and focusing on the reconstruction and integration of social networks. Based on trust, norms, and reciprocal networks, local government takes the cultivation and expansion of social capital as the basic work of post-disaster reconstruction. To build a platform for villagers to participate in political, social, and cultural activities, various measures can be taken, such as holding collective activities, promoting the establishment of village-level mutual-aid organizations, and organizing public cultural activities.

The results of this study not only deepen our understanding on the impact of social capital and social networks during the disaster-recovery process, but also contribute to revealing the role that local government plays in post-disaster recovery and community participation. Finally, due to the limitations of our sample and the heterogeneity of China's rural regions, the external validity of this research is indecisive; therefore, we expect that future research can contain more samples to fill this gap.

Author Contributions: Conceptualization, Z.L.; methodology, Z.L.; validation, Z.L. and X.T.; formal analysis, X.T. writing —original-draft preparation, Z.L.; writing—review and editing, X.T.; supervision, Z.L.

Funding: The research was funded by the Shanghai Social Science Fund (NO. 2018BGL008).

Acknowledgments: I am grateful to H.X. and L.L. for their great help in writing the early draft.

Conflicts of Interest: The authors declare no conflict of interest. 


\section{Appendix A}

Questionnaire of Section 3.2.2

\begin{tabular}{|c|c|c|c|c|c|c|}
\hline \multirow[b]{2}{*}{ CI1 } & \multirow{2}{*}{$\begin{array}{l}\text { Below, We Would Like to Know Some of the Situations You } \\
\text { Experience in This Village. From the Possible Scenarios Below, } \\
\text { Please Choose the Answer Closest to Your Actual Situation. } \\
\text { I feel that I have close contact with other villagers. }\end{array}$} & \multicolumn{5}{|c|}{$\begin{array}{c}1 \text { Almost None } \\
2 \text { Sometimes } \\
3 \text { Often } \\
4 \text { Almost always } \\
9 \text { Don't Know/No Answer }\end{array}$} \\
\hline & & 1 & 2 & 3 & 4 & \\
\hline $\mathrm{CI} 2$ & I have deep feelings for other villagers. & 1 & 2 & 3 & 4 & 9 \\
\hline $\mathrm{CI} 3$ & Sometimes, if I need advice, I will ask the other villagers. & 1 & 2 & 3 & 4 & 9 \\
\hline CI4 & I often help other villagers & 1 & 2 & 3 & 4 & 9 \\
\hline CI5 & Local government has done very little for this village. & 1 & 2 & 3 & 4 & 9 \\
\hline CI6 & The village committee is very concerned about the village. & 1 & 2 & 3 & 4 & 9 \\
\hline $\mathrm{CI} 7$ & The village committee handles affairs for their own benefit. & 1 & 2 & 3 & 4 & 9 \\
\hline $\mathrm{CI} 8$ & The village committee does not listen to the opinions of villagers. & 1 & 2 & 3 & 4 & 9 \\
\hline CI9 & I have almost no influence on this village. & 1 & 2 & 3 & 4 & 9 \\
\hline CI10 & $\begin{array}{l}\text { If there are major problems in this village, villagers will get together to } \\
\text { solve them. }\end{array}$ & 1 & 2 & 3 & A & 9 \\
\hline CI11 & I have no friends in this village to rely on. & 1 & 2 & 3 & 4 & 9 \\
\hline CI12 & I believe that my neighbor will help me if there is an emergency. & 1 & 2 & 3 & 4 & 9 \\
\hline CI13 & I feel good when my neighbors do good things. & 1 & 2 & 3 & 4 & 9 \\
\hline $\mathrm{CI} 14$ & $\begin{array}{c}\text { If I am in a hurry, even people I do not know in this village will be } \\
\text { willing to help. }\end{array}$ & 1 & 2 & 3 & 4 & 9 \\
\hline CI15 & I plan to continue living in this village in the next few years. & 1 & 2 & 3 & 4 & 9 \\
\hline CI16 & I will live in this village for a long time. & 1 & 2 & 3 & 4 & 9 \\
\hline CI17 & I think this village is very suitable for me to live in. & 1 & 2 & 3 & 4 & 9 \\
\hline $\mathrm{CI} 18$ & For me, it is important to continue living in this village. & 1 & 2 & 3 & 4 & 9 \\
\hline CI19 & Living in this village, I feel very comfortable, just like at home. & 1 & 2 & 3 & 4 & 9 \\
\hline $\mathrm{CI} 20$ & I often feel that I am a member of this village. & 1 & 2 & 3 & 4 & 9 \\
\hline $\mathrm{CI} 21$ & The identity of being a villager in this village is of no importance to me. & 1 & 2 & 3 & 4 & 9 \\
\hline $\mathrm{CI} 22$ & I think I am a member of this village. & 1 & 2 & 3 & 4 & 9 \\
\hline
\end{tabular}

\section{References}

1. National Disaster Reduction Committee Office. 2013 National Natural Disasters General Situation. Disaster Reduct. China 2014, 3, 26-29. (In Chinese)

2. Tierney, K.J. From the Margins to the Mainstream? Disaster Research at the Crossroads. Annu. Rev. Sociol. 2007, 33, 503-525. [CrossRef]

3. Vallance, S. Disaster recovery as participation: Lessons from the Shaky Isles. Nat. Hazards 2015, 75, 1287-1301. [CrossRef]

4. Zhao, Y.; Deng, D.; Li, R. Social Capital in the Wenchuan Earthquake Affected Area. China Soft Sci. 2010, 8 , 91-98. (In Chinese)

5. Soloman, S. Mobilizing. Social Support Networks in Times of: Disaster. Trauma and Its Wake; Routledge: London, UK, 2014; pp. 260-291.

6. Shi, P. On the role of government in integrated disaster risk governance-Based on practices in China. Int. J. Disaster Risk Sci. 2012, 3, 139-146. [CrossRef]

7. Zhao, Y. Social Capital and Postdisaster Recovery: A sociological study of natural Disaster. Sociol. Stud. 2007, 5, 164-187. (In Chinese)

8. Tönnies, F. Community and Society: Gemeinschaft und Gesellschaft; Dover Publications: New York, NY, USA, 1963.

9. Maciver, R.M. Community: A Sociological Study; The Macmillan Company: New York, NY, USA, 1917.

10. Dotson, F. Community. In Encyclopedia Dictionary of Sociology; Dushkin Publishing Group: Guiford, CT, USA, 1986. 
11. Bradshaw, T.K. The Post-Place Community: Contributions to the Debate about the Definition of Community. Community Dev. 2008, 39, 5-16. [CrossRef]

12. Wu, J. The Limited Intervention of Grassroots Party Organization: The Logic of Winning of the Two committee Candidates in Urban Community—Based on the Policy Text Analysis. J. Huazhong Agric. Univ. (Soc. Sci. Ed.) 2019. (In Chinese) [CrossRef]

13. Putnam, R.D. Bowling alone:the collapse and revival of American communit. In Proceedings of the ACM Conference on Computer Supported Cooperative Work, Philadelphia, PA, USA, 2-6 December 2000.

14. Geis, D.E. By Design: The Disaster Resistant and Quality-of-Life Community. Nat. Hazards Rev. 2000, 1, 151-160. [CrossRef]

15. Petak, W.J. Emergency Management: A Challenge for Public Administration. Public Adm. Rev. 1985, 45, 3-7. [CrossRef]

16. Luo, J.; Man, S.; Kunhao, Y. A Sociological Analysis of the "Strong Central, Weak Local" Pattern of Trust in Government: Based on Three Stage Tracking Data after the Wenchuan Earthquake. Soc. Sci. China 2018, 39, 5-25. [CrossRef]

17. Amendola, A.; Linnerooth-Bayer, J.; Okada, N.; Shi, P. Towards integrated disaster risk management: Case studies and trends from Asia. Nat. Hazards 2008, 44, 163-168. [CrossRef]

18. Maskrey, A. Disaster Mitigation: A Community Based Approach; Oxfam: Oxford, UK, 1989.

19. Meyer, M.A. Social Capital in Disaster Research. Handbook of Disaster Research; Springer-Verlag: Berlin, Germany, 2018.

20. Bourdieu, P. The Forms of Capital. In Handbook of Theory and Research for the Sociology of Education; Richardson, J., Ed.; Greenwood Press: New York, NY, USA, 1986; pp. 240-258.

21. Scoones, I. Sustainable Rural Livelihoods: A Framework for Analysis; Institute of Development Studies: Brighton, UK, 1998.

22. Serrat, O. The Sustainable Livelihoods Approach. In Knowledge Solutions; Springer: Singapore, 2017; pp. 21-26.

23. Nakagawa, Y.; Shaw, R. Social capital: A missing link to disaster recovery. Int. J. Mass Emerg. Disasters 2004, 22, 5-34.

24. Haines, V.A.; Jeanne, S.H.; John, J. Exploring the Determinants of Support Provision: Provider Characteristics, Personal Networks, Community Contexts, and Support Following Life Events. J. Health Soc. Behav. 1996, 37, 252-264. [CrossRef] [PubMed]

25. Schuller, T.; Baron, S.; Field, J. Social capital: A review and critique. In Social Capital: Critical Perspectives; Oxford University Press: New York, NY, USA, 2000; pp. 1-38.

26. Sung, H.; Mark, S. The Effects of Natural Disasters on Social Trust: Evidence from South Korea. Sustainability 2018, 10, 2973. [CrossRef]

27. Nahapiet, J.; Ghoshal, S. Social Capital, Intellectual Capital, and the Organization Advantage. Acad. Manag. Rev. 1998, 23, 242-266. [CrossRef]

28. Hwang, K.K. Face and Favor: The Chinese Power Game. Am. J. Sociol. 1987, 92, 944-974. [CrossRef]

29. Luo, J. Guanxi Revisited: An Exploratory Study of Familiar Ties in a Chinese Workplace. Manag. Organ. Rev. 2011, 7, 329-351. [CrossRef]

30. Walder, A. Communist Neo-Traditionalism: Work and Authority in Chinese Industry; University of California Press: Berkeley, CA, USA, 1988.

31. Gotham, K.F.; Cheek, W. Postdisaster Recovery and Rebuilding. In The Sage Handbook of the 21st Century City; Sage: London, UK, 2017; pp. 284-285.

32. Xu, J.; Lu, Y. A comparative study on the national counterpart aid model for postdisaster recovery and reconstruction: 2008 Wenchuan earthquake as a case. Disaster Prev. Manag. 2013, 22, 75-93. [CrossRef]

33. Zhang, H.; Zhang, X.; Comfort, L.; Chen, M. The emergence of an adaptive response network: The April 20, 2013 Lushan, China Earthquake. Saf. Sci. 2016, 90, 14-23. [CrossRef]

34. Rolf, L. Invented Communities and Social Vulnerability: The Local Postdisaster Dynamics of Extreme Environmental Events. Sustainability 2018, 10, 4457. [CrossRef]

35. Gittell, R. Community Organizing: Building Social Capital as a Development Strategy; Sage Publications: Newbury Park, CA, USA, 1998; p. 15.

36. Putman, R.D. Tuning in, Tuning out: The Strange Disappearance of Social Capital in America. Political Sci. Politics 1995, 28, 664-683. [CrossRef] 
37. Aguirre, E. The Lack of Warning before the Saragosa Tornado. Int. J. Mass Emerg. Disasters 1988, 6, 65-74.

38. Li, Z.; Tan, X. Revitalization of Trust in Local Government after Wenchuan Earthquake: Constraints and Strategies. Sustainability 2018, 10, 4030. [CrossRef]

39. Krackhardt, D. The Strength of Strong Ties: The Importance of Philos in Organizations. In Networks and Organization; Harvard Business School Press: Brighton, MA, USA, 1992.

40. Burt, R.S. The Contingent Value of Social Capital. Adm. Sci. Q. 1997, 42, 339-365. [CrossRef]

41. Cheung, C.; Kam, P.K. Bonding and Bridging Social Capital Development by Social Workers. J. Soc. Serv. Res. 2010, 36, 402-413. [CrossRef]

42. Baylis, K.; Gong, Y.; Wang, S. Bridging versus Bonding Social Capital and the Management of Common Pool Resources. Land Econ. 2018, 94, 614-631. [CrossRef]

43. Xu, C. The Constitution; China Renmin University Press: Beijing, China, 2009; pp. 257-258. (In Chinese)

44. Feng, J. Zhongxian County Cadre; Peking University: Beijing, China, 2010.

45. Uzzi, B. Social Structure and Competition in Interfirm Networks: The Paradox of Embeddedness. Adm. Sci. Q. 1997, 42, 35-67. [CrossRef]

46. Lin, N.; Cook, K.; Burt, R.S. Social Capital: Theory and Research; Walter de Gruyter: New York, NY, USA, 2001; pp. 365-385.

47. Granovetter, M.S. Economic Action and Social Structure: The Problem of Embeddedness. Am. J. Sociol. 1985, 91, 481-510. [CrossRef]

48. Putnam, R.D. Bowling Alone: America's Declining Social Capital. J. Democr. 1995, 61, 65-78. [CrossRef]

49. Zheng, Z.; Zhong, Y. Individualized Society and Private Community: Criticism Based on Chinese Community Practice. Study Pract. 2012, 6, 91-98. (In Chinese)

50. Kish, L. A Procedure for Objective Respondent Selection within the Household. Publ. Am. Stat. Assoc. 1949, 44, 380-387. [CrossRef]

51. O’Brien, S.M.; Dunson, D.B. Bayesian Multivariate Logistic Regression. Biometrics 2004, 60, $739-746$. [CrossRef]

52. Plummer, J.; Taylor, J.G. Key Factors and Processes Affecting Participation. In Community Participation in China: Issues and Processes for Capacity Building; Earthscan: London, UK, 2004.

53. Christens, B.D.; Peterson, N.A.; Speer, P.W. Community participation and psychological empowerment: Testing reciprocal causality using a cross-lagged panel design and latent constructs. Health Educ. Behav. 2011, 38, 339-347. [CrossRef] [PubMed]

54. Pyles, L.; Svistova, J.; Ahn, S.; Birkland, T. Citizen participation in disaster recovery projects and programmes in rural communities: A comparison of the Haiti earthquake and Hurricane Katrina. Disasters 2018, 42, 498-518. [CrossRef] [PubMed]

55. Li, Z.; Luo, J. A Preliminary Study on the Trust Mechanism of Self-Organizational Governance in Rural Communities-Taking a Villager Economic Cooperation Organization as an Example. Manag. World 2012, 10, 83-93. (In Chinese)

56. Marsden, P.; Friedkin, N. Network Studies of Social Influence. In Advances in Social Network Analysis: Research in the Social and Behavioral Sciences; SAGE Publications Inc.: Thousand Oaks, CA, USA, 1994; pp. 3-25.

57. Ikenberry, G.J.; Fukuyama, F. Trust: The Social Virtues and the Creation of Prosperity. Foreign Aff. 1996, 75, 143. [CrossRef]

58. Xiong, H.; Payne, D. Characteristics of Chinese rural networks: Evidence from villages in central China. Chin. J. Sociol. 2017, 3, 74-97. [CrossRef]

59. Luo, J.; Ye, Y.C. Neither collectivism nor individualism: Trust in the Chinese guanxi circle. J. Trust Res. 2012, 2, 53-70. [CrossRef]

60. Bates, F.L.; Walter, G. Disasters and Social Change. In The Sociology of Disasters; Franco Angeli Press: Milan, Italy, 1987; pp. 291-330.

61. Fu, P. Social Capital Issues in Postdisaster Reconstruction of Poor Villages. J. Humanit. 2010, 2, 167-174. (In Chinese)

(C) 2019 by the authors. Licensee MDPI, Basel, Switzerland. This article is an open access article distributed under the terms and conditions of the Creative Commons Attribution (CC BY) license (http:// creativecommons.org/licenses/by/4.0/). 